\title{
Role of psychiatric nurse for client receiving anti- psychotic drugs
}

\section{Abstract}

Mental illness is growing in its magnitude. Even the normal person has minor issues like stress and anxiety due to various factors. The clients receiving the psychiatric consultation need support and special care by psychiatric nurse, these clients receive various drugs which have various side effects which needs to be taken care of, so this article deals with the various interventions which a psychiatric nurse can do in this regard.
Volume 6 Issue 3 - 2018

Bushra Mushtaq

Psychiatry Nursing Scholar, India

Correspondence: Bushra Mushtaq, PG Psychiatry Nursing Scholar, Srinagar, India, Tel 700690856I,

Email bushra.mushtaq77@gmail.com

Received: May 17, 2018 | Published: June 05, 2018

\section{Introduction}

Anti-psychotics are drugs which are used for the treatment of psychotic diseases and symptoms. Anti-psychotics are also called as $\mathrm{D}_{2}$-receptor blockers (dopamine receptors). These drugs are indicated in:

a. Organic psychiatric disorders; like Delirium, Dementia.

b. Non-Organic psychotic disorders; like Schizophrenia, Mania.

c. Neurotic disorders.

d. Medical disorders; like Huntington's chorea, Nausea, and Vomiting.

There are various side effects associated with antipsychotics like;

a. Autonomic side-effects like dry mouth, constipation.

b. Extra-pyramidal side-effects like Parkinson's.

c. Nervous system side-effects like seizures.

d. Metabolic side-effects like weight gain.

To prevent and minimize these side effects, the psychiatric nurse has a role to play while dealing with the client receiving antipsychotics.

\section{Nursing diagnosis}

\section{Risk of injury related to Central nervous system effects} Interventions: ${ }^{2}$

i. Provide different comfort measures to the client like positioning of legs and arms.

ii. Provide safety measures to client to minimize the injuries like raising side rails, adequate lighting.

iii. Adequate and continuous monitoring of client after the drug is given to the client.

iv. Educate the client and family members regarding side-effects of drug for better understanding and cooperation.

\section{Impaired physical activity related to extra pyramidal effect}

Interventions:

i. Provide the safe environment to the client like removing of harmful or injurious objects in environment.

ii. Report the doctor if there are excess tremors.

iii. Assist the client in performing the activities so that client gets minimal stresses out.

iv. Make client to sit comfortably till the motor restlessness gets relieved.

Impaired urinary elimination related to drug autonomic side-effect

Interventions:

a) Maintain input-output chart.

b) Maintain adequate fluid intake.

c) Promotion of normal voiding patterns.

d) Administer drugs as per prescription.

Risk of activity intolerance related to sedation, weakness (side-effects)

Interventions:

a) Minimize the excess exhaustion of the client and provide adequate rest.

b) Help the client to perform minor activities if any.

c) Educate client and family not to operate any dangerous equipment's.

\section{General responsibilities of a psychiatric nurse}

a. Client is instructed not to abruptly stand to prevent fall due to orthostatic hypotension. 
b. Check vital signs before and after medication.

c. Client is instructed to take sips of water frequently for avoiding of dry mouth; application of glycerine is also recommended.

d. Increased intake of fluid and high fiber diet is recommended to avoid constipation.

e. Educate the client not to drive after taking medication.

f. Educate the client to wear full sleeves and eye gears while going out in sun to avoid photosensitivity.

\section{Acknowledgements}

None.

\section{Conflict of interest}

The author declares that there is no conflict of interest.

\section{References}

1. Niraj Ahuja. A short Textbook of Psychiatry. 7th ed. India: Jaypee Publications; 2011. $272 \mathrm{p}$.

2. Sreevani R. A Guide to Mental Health and Psychiatric Nursing. 3rd ed. India: Jaypee Publications; 2010. 414 p. 